\title{
CAREER DECISION AND K TO 12 CURRICULUM EXITS OF SENIOR HIGH SCHOOL STUDENTS
}

\author{
Maurice Dence B. Bacaling* \\ Sta. Cruz National High School, Sta. Cruz, Davao del Sur, Philippines
}

\begin{abstract}
The first batch of the K to 12 Curriculum are about to graduate this year and many senior high students were hesitant and worried if they will be able to land a job, a business on his own, proceed to college or take higher vocational course. To address these concerns and worries of the Grade 12 graduating students, an action research was proposed. The purpose of this study was to examine the career decision of the students and how it relates to the $\mathrm{K}$ to 12 Curriculum Exits (Trabaho, Negosyo, Kolehiyo, and Middle Skills Development). This study used the mixed method design. Research-made questionnaire were administered to 324 students using the universal sampling method. On the other hand, eight students were selected as participants for focus-group discussion (FGD). Percentage and ranking were utilized as statistical tool for this study. Results revealed that majority of the student's career decision after graduation will enroll to college/university (57.4\%), followed by find a job (34.9\%), enroll to a vocational school (4.9\%), have his own business (1.9\%), and some were undecided $(0.9 \%)$. Findings were utilized by teachers and career advocates by creating a program that will help the students decide of what to take after graduation. Thus, a threeday senior high school Curriculum Exits - Fair (Job-Fair, Business Demonstrations, College/University and Vocational fair) were implemented.
\end{abstract}

Keywords: career decision, K to 12, senior high school

\section{Introduction}

Career decision is very important for a senior high school graduating student to take although doing it is a lifelong process (Georgia Career Information Center, 2013). It is a continuous process throughout the development of a person.

Prior to the implementation of the $\mathrm{K}$ to 12 Curriculum program, problems and challenges were already identified by the Department of Education based on their studies. Among of those, Philippines is the last country in Asia and one of only three countries in the world (the other two being Djibouti and Angola of Africa) with a ten-year pre-university program. In addition, poor quality of basic education was reflected in the inadequate preparation of high school graduates for the world of work which contributes to the relatively high unemployment rate among the young and the educated (Care, E. \& Valenzuela, E. (2012).

As the first batch of the $\mathrm{K}$ to 12 Curriculum program is about to graduate, many senior high school students were hesitant and worried if they will be able to land a job, establish a business on his/her own, proceed to college or take higher vocational course. Although, the DepEd has already prepared the students to decide the possible career exits they will have through the Career Guidance Program (DO 41, s. 2015), but still uncertainty still do exist to the minds of the Grade 12 students of Sta. Cruz National High School.

To address these concerns and worries of the Grade 12 graduating students, the Senior High School focal person proposes to do this action research. 


\section{General Objectives}

This study aimed to find out the career decisions of the Grade 12 graduating senior high school students of Sta. Cruz National High School and how it relates to the K to 12 Curriculum Exits. Specifically, it aimed:

1. determine the career decision of the Grade 12 students after graduation.

2. identify whether the career decision of the Grade 12 students after graduation were based on the $\mathrm{K}$ to 12 Curriculum Exits - Trabaho, Negosyo, Kolehiyo, and Middle Skills Development.

3. develop an Intervention Program that will help Grade 12 graduating students strengthen their career plans after graduation.

\section{Significance $f$ the Study}

This study examined the possible career decision exits of the Grade 12 graduating students of Sta. Cruz National High School based on the K to 12 Curriculum Exits such as Trabaho, Negosyo, Kolehiyo, and Middle Skills Development.

Through this action research, teachers and career advocates able to create programs and interventions on how to strengthen the student's career planning and decision making. Also, the students are the benefactors of the result of the study particularly in helping them decide of what career to pursue after graduation.

Thus, in the context of conducting further research, this study provides an avenue to conduct another action research such as a tracer study. Moreover, the information that generated from this study will be used to trace the students' status whether the career decisions they take were realized based on the Curriculum Exits provided.

\section{Scope and Limitation}

This mixed method research were intended to all Grade 12 graduating senior high school students who are currently enrolled at Santa Cruz National High School, in the Division of Davao del Sur.

This study was conducted during the month of January 2018.

\section{Research Questions}

This study sought to find out what are the career decision of the Grade 12 graduating students. This answered the following specific questions:

1. What is the profile of the students in terms of:

1.1 Gender;

1.2 Age;

1.3 Track;

1.4 Strand? 
2. What is the career decision of the Grade 12 students based on the Curriculum Exits presented to them in terms of:

\subsection{Trabaho;}

2.2 Negosyo;

2.3 Kolehiyo;

2.4 Middle Skills Development?

\section{Methods}

\section{Research Design}

This study used the mixed method design which focused on the collecting, analyzing, and mixing both quantitative and qualitative data in a single study (Creswell, J. W., \& Plano Clark, V. L., 2011). A purposive sampling was employed in selecting the sample wherein all the Grade 12 graduating senior high school students were the participants of this study. Also, a purposeful random sampling was utilized in the selection of focus group discussion (FGD) to provide in-depth data about the subject matter under this study (Patton, 1990). Eight students from the different strands were chosen to represent as the FGD participants.

\section{Research Locale}

This study was conducted in Santa Cruz National High School, Division of Davao del Sur.

\section{Participants}

The main research participants were the Grade 12 senior high school students of Santa Cruz National High School, this school year 2017-2018.

\section{Instruments}

A researcher-made questionnaire was used as a survey tool to generate what career decision of the students after they graduate senior high school. The research-made questionnaire was composed of two parts. Part I was the demographic survey in which the participants were asked to answer the following: gender, age, track, and strand. The Part II, on the other hand, were the Curriculum Exits to which students may choose after they graduate from senior high school. This may either be Trabaho, Negosyo, Kolehiyo, and Middle Skills Development.

Aside from the survey questionnaire, the researcher intended to conduct Focus Group Discussion (FGD) wherein eight (8) Grade 12 senior high school students were selected and represented the eight strand or course offering of the school. The school offers the following strand: General Academic Strand (GAS), Science, Technology, Engineering, and Mathematics (STEM), Humanities and Social Sciences (HUMSS), Accountancy, Business, and Management (ABM), Home Economics - Caregiving, Home Economics - Bread and Pastry Production, Food and Beverages Servicing, and Cookery, Industrial Arts - Electrical Installation and Maintenance, and ICT - Computer Systems Servicing. The purpose of this FGD was to understand the reasons of student's career decision and to strengthen the result of the study. 


\section{Data Gathering Procedures}

In collecting the data, the researcher asked permission from the school head to conduct this mixed method research. After the approval, the Grade 12 students were asked to answer the researcher-made questionnaire for the survey. Then, a purposeful random sampling was conducted for the identification of the selected informants of this inquiry or focus-group discussion (FGD) for deeper understanding of the study. In-depth interview was conducted to the eight selected students from each strand during vacant times to avoid disruption of classes.

The collected data were treated using the following simple statistics, i.e., frequency, percentage and ranking. Further, responses from the FGD were gathered to support to the results of the survey conducted.

\section{Findings and Analysis}

The results of the study entitled, "Career Decision and K to 12 Curriculum Exits of Senior High School students" are presented in this section.

\section{Profile of the Students}

1.1 Based on the data of gender, from a total of 324 senior high school students, 164 were female (51\%) and 160 were male $(49 \%)$.

Table 1. Profile of the students based on Gender

\begin{tabular}{lll}
\hline Gender & $f$ & Percentage \\
\hline Male & 160 & $49 \%$ \\
\hline Female & 164 & $51 \%$ \\
\hline Total & 324 & $100 \%$ \\
\hline
\end{tabular}

1.2 The age of the students involved in this study ranged from 17 years old to 23 years old. Students who are of age 18 were the highest number of participants with a percentage of $51.2 \%$.

Table 2. Profile of the students based on Age

\begin{tabular}{lll}
\hline Age & $F$ & Percentage \\
\hline 17 & 103 & $31.8 \%$ \\
\hline 18 & 166 & $51.2 \%$ \\
\hline 19 & 33 & $10.2 \%$ \\
\hline 20 & 17 & $5.2 \%$ \\
\hline 21 & 4 & $1.2 \%$ \\
\hline
\end{tabular}

1.3 Most of the respondent-students of the study were Technical Vocational and Livelihood (TVL) track with a percentage of 55\%. The Academic track respondents-students were only $45 \%$.

Table 3. Profile of the students based on Track

\begin{tabular}{lll}
\hline Track & $F$ & Percentage \\
\hline Academic & 145 & $45 \%$ \\
\hline Technical Vocational and Livelihood (TVL) & 179 & $55 \%$ \\
\hline Total & 324 & $100 \%$ \\
\hline
\end{tabular}


1.4 The respondent-students were from Academic Track with four strands namely General Academic Strand (GAS) with 9\%, Science, Technology, Engineering, and Mathematics (STEM) with 12\%, Humanities and Social Sciences (HUMSS) with 13\%, and Accountancy, Business, and Management $(\mathrm{ABM})$ with $10 \%$. While for Technical Vocational and Livelihood track with four offerings namely Home Economics - Caregiving with 10\%, Home Economics - Bread and Pastry Production/Food Beverages Servicing/Cookery with 11\%, ICT - Computer Systems Servicing with 14\% and Industrial Arts - Electrical Installation and Maintenance with 20\%. Most of the participants were Electrical Installation and Maintenance students.

Table 4. Profile of the students based on Strand

\begin{tabular}{lll}
\hline STRAND & $f$ & Percentage \\
\hline General Academic Strand (GAS) & 30 & $9 \%$ \\
\hline $\begin{array}{l}\text { Science, Technology, Engineering, and } \\
\text { Mathematics (STEM) }\end{array}$ & 39 & $12 \%$ \\
\hline $\begin{array}{l}\text { Humanities and Social Sciences } \\
\text { (HUMSS) }\end{array}$ & 43 & $13 \%$ \\
\hline $\begin{array}{l}\text { Accountancy, Business, and Management } \\
\text { (ABM) }\end{array}$ & 33 & $10 \%$ \\
\hline $\begin{array}{l}\text { Home Economics - Caregiving } \\
\text { Home Economics - Bread and Pastry }\end{array}$ & 32 & $10 \%$ \\
$\begin{array}{l}\text { Production/Food Beverages } \\
\text { Servicing/Cookery }\end{array}$ & 37 & $11 \%$ \\
\hline $\begin{array}{l}\text { ICT - Computer Systems Servicing } \\
\text { Industrial Arts - Electrical Installation } \\
\text { and Maintenance }\end{array}$ & 64 & $14 \%$ \\
\hline
\end{tabular}

\section{Career Decision of Grade 12 students Based on the K to 12 Curriculum Exits}

Students were asked what their career decision after graduation will be based on $\mathrm{K}$ to 12 Curriculum Exits (Trabaho, Negosyo, Kolehiyo, and Middle Skills Development). Based on the survey, results show that students decide to continue their college (Kolehiyo) with $57.4 \%$, followed by finding a job (Trabaho) with $34.9 \%$, Middle Skills Development with 4.9\%, Negosyo with 1.9\%. Also, it revealed that some will go to college while they are having some part-time job which was classified as Other options in the survey questionnaire. It has $0.9 \%$.

The result of the survey was supported with the FGD conducted to eight students from different strands. They were interviewed and were asked about their reasons why they choose those career options. Among the eight (8) FGD respondents, six (6) answered they wanted to continue their studies and enter to college. Two (2) of the respondents wanted to find a job because they want to help their parents due to financial difficulty.

Majority of the students preferred to proceed to college (Kolehiyo) simply because Filipinos believe that education plays an important role in the country's progress and it helps people to become better and productive citizens. Aside from that education helps solve the unemployment problem which poses a hindrance to the growth of the nation (De Guzman, 2015). 
Table 5. Career Decision based on $\mathrm{K}$ to 12 Curriculum Exits

\begin{tabular}{llll}
\hline Curriculum Exits & $f$ & Percentage & Rank \\
\hline Trabaho & 113 & $34.9 \%$ & 2 \\
\hline Negosyo & 6 & $1.9 \%$ & 4 \\
\hline Kolehiyo & 186 & $57.4 \%$ & 1 \\
\hline Middle Skills & 16 & $4.9 \%$ & 3 \\
Development & & & 5 \\
\hline Other options & 3 & $0.9 \%$ & 5 \\
\hline
\end{tabular}

\section{Conclusions}

The shift of curriculum from Basic Education Curriculum (BEC) to K to 12 Curriculum emphasized honing the skills and career pathways of Filipino learners. K to 12 Curriculum prepared students to be globally competent individuals. Moreover, it was emphasized in the senior high school program the importance of career decision and the four curriculum exits (Trabaho, Negosyo, Kolehiyo, and Middle Skills Development.

Based on the findings, majority of the senior high school graduating students were geared towards pursuing their studies to higher education (Kolehiyo). Also, it is significantly noticeable that some students wanted to find a job after graduation (Trabaho). Although, career guidance is being highlighted in the curriculum program, there are still students who can't decide of what to take after graduation.

\section{Further Actions Done}

Given the results of the study, the researcher recommended to the principal to conduct a three-day Senior High School Curriculum Exits Fair which would aim to help the first batch of K to 12 graduates land the different curriculum exits - Trabaho, Negosyo, Kolehiyo, \& Middle Skills Development. The three-day activity corresponds to Job Fair, Business Fair, and College/University and Vocational School Fair for the students to decide what career they want after graduation.

After the three-day Senior High School Curriculum Exit Fair, the researcher will propose and conduct another action research study on the impact of the said activity to graduating students. Furthermore, the first batch of $\mathrm{K}$ to 12 graduates are subjects for a tracer study -- to locate and to know where the students landed after the graduation from high school whether they find a job (Trabaho), engage into business (Negosyo), enroll to college/university (Kolehiyo), or enroll to a Technical Vocational school (Middle Skills Development).

\section{Acknowledgements}

I would like to thank the first batch of the K to 12 graduates of Sta. Cruz National High school who participated in this study. I also wish to thank my friends namely, Dina, Germe, Melanie, Christian, Rio Rose for extending their financial support for me to present the study to the conference. To my principal, Mr. Nestor R. Amoroso and to the faculty members of Sta. Cruz National High School, Philippines, thank you for your moral support. To the Department of Education, Division of Davao del Sur, Philippines, thank you for allowing me to present my action research in the International Conference arena.

\section{References}

Care, E. \& Valenzuela, E. (2012). Analysis of Basic Education of the Philippines: Implications for the K to 12 Education Program, Jan. 2012.

Creswell, J. W., \& Plano Clark, V. L. (2011). Designing and conducting mixed methods research (2nd ed.). Thousand Oaks, CA: Sage Publications, Inc. 
Maurice Dence B. Bacaling / Career Decision and K to 12 Curriculum Exits of....

De Guzman, S. (2015). Education our youth. The Philippine Star. https://www.philstar.com/opinion/2015/10/04/1507199/educating-our-youth\#y1QWTyv4uH5lKt3D.99

DO 41, s. 2015 Senior High School Career Guidance Program and Early Registration

Georgia Career Information Center (2013). Career Decision Making. Division of Student Affairs, Georgia State University. http://ipcu.gcic.edu/careerMAIN.htm

Patton, M. (1990). Qualitative evaluation and research methods. 2nd ed. Newburry Park, Ca. Sage. 